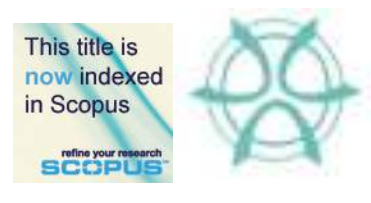

PLANNING MALAYSIA:

Journal of the Malaysian Institute of Planners

SPECIAL ISSUE IV (2016), Page 181 - 196

\title{
THE RUKUN WARGA-BASED 3RS AND WASTE BANK AS SUSTAINABLE SOLID WASTE MANAGEMENT STRATEGY
}

\author{
Sherly Towolioe ${ }^{1}$, Ariva Sugandi Permana ${ }^{2}$ \& Norsiah A. Aziz ${ }^{3}$, Chin Siong $\mathrm{Ho}^{4}$ \& \\ Dario G. Pampanga ${ }^{5}$ \\ 1,2,3,4,5 Faculty of Built Environment \\ UNIVERSITI TEKNOLOGI MALAYSIA
}

\begin{abstract}
Communities store a potential power to support overall performance of urban solid waste management through various creative and innovative arrangements. In Indonesia, the Rukun Warga (RW) is the lowest hierarchy of community organizational system which can implement creative and innovative arrangements to support solid waste management activities with less financial requirement. This study observed RW-based activity on fifty RWs with 412 respondents in terms of 3Rs, household waste separation, waste recycling business and waste bank system undertaken by the community for the sake of cleanliness and income-earning. The result shows that the correlation between level of the activity of the RWs communities in undertaking 3Rs, recycling business and waste bank, and the perceived cleanliness by the community members was validated. It is also showed positive results such as improved urban environment and provided strong push-factor influencing the community members to join the movement and the activities towards sustainable solid waste management are not always cost-intensive activities but a sociallybounded engagement would also workable.
\end{abstract}

Keyword: Rukun Warga (RW), 3Rs, community-based solid waste management, waste separation, waste bank, cost-intensive waste management

\section{INTRODUCTION}

The division of administrative regions in Indonesia on the first level according to the Constitution of the Republic of Indonesia 1945 Chapter VI on Local Government, Article 18, and Paragraph 1 is a provincial unit. A provincial unit is divided further into districts (Kabupaten) and municipalities (Kota) that have an equivalent level, then a district is divided into sub-districts (Kecamatan). The lowest administrative division of a subdistrict in a municipality is wards (Kelurahan). At the same level with a ward, the subdistricts in a district is divided into villages (Desa). Kelurahan and Desa are thus the lowest formal administrative and political division.

In the context of non-formal sub-division, Rukun Warga (RW) is the lowest level of territorial division. The RW is under the Kelurahan or Desa. Thus, the Kelurahan or Desa may consist of several RWs depending on geographical condition and population size of the Kelurahan or Desa. This is a non-formal territorial sub-division, because they 
Sherly Towolioe, Ariva Sugandi Permana, Norsiah A. Aziz, Chin Siong Ho \& Dario G. Pampanga

The Rukun Warga-Based 3Rs and Waste Bank as Sustainable Solid Waste Management Strategy

are not accommodated in the Constitution and its formation is rather through local community meetings set by the sub-district or Kelurahan or Desa. RW is led by a chairman elected by citizens as government partners in maintaining and preserving the values of a society that is based on mutual cooperation and kinship as well as help improve the smooth administration tasks such as implementing a sustainable waste management through 3Rs and waste banks. The study area, the Makassar City consists of 14 districts, 143 sub district, 971 RW, and 313,168 households (Central Bureau of Statistics of Makassar, 2013).

The study area, is one of the cities with insufficient solid waste management system in many aspects. As a result, policy and implementation of SWM in the context of developing city have not been appropriately established. The absence of appropriate policies on sustainable development in the proposed study area has led to a situation where the city is leading towards wrong direction away of green and clean city.

The local government of Makassar city is currently facing various issued related to solid waste management putting the environment at risk. The environmental risks identified are (1) the volume of waste generated in Makassar City is continuously increasing, (2) insufficient policy and legal aspect pertaining to sustainable solid waste management (3) the poor implementation and operationalization of government policies related to solid waste management particularly the cooperation between the local government and the community, and (4) poor quality and inadequacy of solid waste transportation, including insufficiency in financial support for a comprehensive sustainable solid waste management program by the local government. More often, the equipment such as truck containers are ageing, with no container cover causing wastes to scatter on the street while transporting, and it emits bad odor. Another issue on solid waste collection by the government is the inconsistency frequency of collection of wastes from the sources (Dilla and Natsir, 2007).

We observed that in Indonesia, the issue of SWM is seemingly a major concern at all levels of government, as local government yet unable to accomplish sustainable solid waste management practices, perhaps due to some constraints like institutionalizing operational policies, inadequate financial support, and the availability of infrastructure related to SWM (Meidiana and Gamse, 2010). However, a few of sustainable solid waste management (SWM) practices are presently in place in some cities in Indonesia such as Makassar City. In case of Makassar City, the activities were initiated by the RW organization.

\section{SOME ASPECTS OF SWM PRACTICES IN THE STUDY AREA}

There are numerous practices in sustainable solid waste management, where one of the easiest and most practical activities is the Reducing, Reusing and Recycling or 3Rs. However, these 3 Rs would not take place without waste separation at first place, particularly at household level where the primary source of municipal waste originates. Visvanathan et al., (2007) argued that even this activity is easy, most people in cities in developing countries do not carry out this activity because of numerous reasons such as lack of knowledge and awareness, motivation, attitude, availability of supporting facility, incentive and opportunity. By this reason, the municipal SWM implementation is hampered persistently. 
The collection of municipal solid waste has been identified as a major problem since in many areas municipal authorities are either unable or unwilling to provide waste collection services to all residents in their jurisdiction. On average, up to $50 \%$ of residents lack collection services in urban areas of low and middle income countries (Parizeau et al., 2006). There are limited opportunities for the development of a sustainable SWM systems as government budgets are limited and more than often, collection is overlooked; only the proper disposal of solid waste is perceived as representing a cost (McBean et al., 2005).

As a comparison with developed countries, Bai and Sutanto (2002) identified that the introduction of the centralized refuse-chute method has basically improved the efficiency collection of domestic household waste. This method has also increased the control on smell and leakage of refuse during the collection and transport of wastes. Moreover the authority has employed solid waste incineration process. Presently, Singapore incinerates $73 \%$ of the total waste which is tantamount to 8,000 tons per day, while the remaining $27 \%$ goes to the sanitary landfill. Over the years, the volume of solid waste incinerated has increased from 1.18 million in 1990 to 2.44 million tons in 2000. On the other hand, in developing countries the practices are largely depending on the households as the primary generator of municipal wastes.

We assert that waste segregation at household level is a key factor that leads to sustainable municipal waste management system because of some reasons. Firstly, 3Rs has a multiplier effect towards zero waste; secondly 3Rs would not be successful without the presence of fundamental activity i.e. waste separation at source; and, thirdly, zero waste is an eventual goal of sustainable SWM. By these reasons, we argue that SWM activities at RW level in is interesting to investigate further.

Matter et al. (2013) stated that the waste segregation is a separation process of the entire waste generated, and it must be done at the very initial stage of overall SWM process. Thus, waste separation at source i.e. at household level is the most economically efficient ways of undertaking sustainable SWM. Waste segregation is commonly done based on the compositional makeup of the waste. Waste segregation ensures safety and enhances recycling ability of waste material that is of key to sustainable solid waste management (Ryu, 2010).

According to World Bank (2007), in most developing cities in Asia, the impending factors towards the implementation of sustainable SWM include lack of support from the local government, insufficient incentives, lack of willingness to implement sustainable SWM from the authority side, and lacks of awareness and feeling of sacrifice from the community side. These have made the solid waste management activities are limited. The community can only do selling the recyclable waste, not even a continuous waste segregation regardless whether or not recyclable wastes exist. There is actually a potential towards zero landfill through gradual change of habits of the waste management stakeholders such as the community or the neighborhood, the government and the business sector. This is also happening in Makassar.

In Makassar city and most cities in Indonesia, the handling of waste is still using the collection, transportation, and disposal in landfill site. The solid waste is collected from the source and then transported to temporary dump site and finally dumped in a landfill. It is therefore far from sustainability principle. Sustainable SWM strategies are thus needed to be pondered and practiced in a sustainable manner in the city. In this case, 
Sherly Towolioe, Ariva Sugandi Permana, Norsiah A. Aziz, Chin Siong Ho \& Dario G. Pampanga

The Rukun Warga-Based 3Rs and Waste Bank as Sustainable Solid Waste Management Strategy

the initial strategies that can be applied include reducing the volume of waste by processing waste into useful products is one method that is very necessary. Reducing waste in household can be done by collecting all wet waste that food scraps and vegetable directly entered into the composter every day. As for the recycling process can be prepare large size plastic bag for separate waste paper, plastic, aluminum, glass, and metal.

Currently, waste management strategies implemented at RW community level is mostly waste separation, recycling and waste bank system. In Makassar, it is recorded only 2105 house hold $(\mathrm{HH})$, or about $1 \% \mathrm{HH}$ conducting voluntary waste separation (Yayasan Peduli Negeri, 2013) whereas the number of HH on Makassar is as much as 313,168 (Central Bureau of Statistics of Makassar, 2013). To support the current strategy, waste segregation becomes very important, otherwise recycling and waste bank may not be able to implement. Separation should be done at the waste generators such as household, schools, offices, community health centers, hospitals, markets, and other places where human living. At each place, it can be prepared at least three activities - four bins are coded, i.e. the bins for rubbish that can be decomposed by microbes (organic waste), the bins for plastic waste or similar, the bins for cans and bottles

Nowadays, Makassar City generates about 5,224 m3/day of waste from the entire city (Central Bureau of Statistic of Makassar, 2014). Public Cleansing Department of Makassar City, a city department that is responsible to carry out SWM, stated that the Final Disposal Site (FDS) Tamangapa approximately receives 2,089 m3 of waste per day. Of the total volume waste generated, there only a maximum of $80 \%$ could be collected, hauled and handled by the government's SWM Agency. The FDS Tamangapa is the only landfill site in the city so far. The remaining waste of $20 \%$ is left uncollected. There are left on street, backyards and water bodies. The most common means of dealing with this waste is by burning it or dumping it to the unused land, in rivers and canals. This has serious environmental consequences, such as local air pollution and increase incidence fire and flooding.

The wastes generated in urban Makassar is generally organic as shown in Table 1 where $72 \%$ while $28 \%$ of the waste are non-organic, such as plastic and paper, among others. With the projected population of 2.2 million in 2015 , and the average assumption of $0.3 \mathrm{~m} 3$ of waste per day, it is estimated that there will be a total of $4.188 \mathrm{~m} 3$ of waste generated per day (Pasang et al., 2007).

Table 1: Waste Generation and Composition of Makassar City Year 2009 - Year 2013

\begin{tabular}{|l|l|l|l|l|l|l|}
\hline No & $\begin{array}{l}\text { Waste } \\
\text { Generation and } \\
\text { Composition }\end{array}$ & Year 2009 & Year 2010 & Year 2011 & Year 2012 & Year 2013 \\
\hline 1. & Volume $\left(\mathrm{M}^{3}\right)$ & 3.680 .03 & 3.781 .23 & 3.923 .52 & 4.057 .28 & 4.188 .26 \\
\hline 2. & Organic $(\%)$ & 79,98 & 76,98 & 74,81 & 72,72 & 71,59 \\
\hline 3. & Inorganic (\%) & 29,02 & 23,02 & 25,19 & 27,28 & 28,41 \\
\hline
\end{tabular}

Source: Public Cleansing Department, 2013

Each household must pay the cost of collecting garbage after garbage collection is done by RW. Each household pays a monthly basis starting from approximately USD 1.5 - US \$ 3.0, based on the household size or house size or income level. In addition to the cost of garbage collection, there is also the cost of transportation and waste disposal. Total costs for transportation and disposal costs depend on the land area of housing. 
The focus of this study is Makassar City in the eastern part of Indonesia. Makassar, formerly known as Ujung Pandang, has a land area of $175.77 \mathrm{~km} 2$. In 2010, the city has a population of 1.339 million. It is the capital city of South Sulawesi and the fourth largest city in Indonesia. The city serves as the business and trading, education, agriculture, and financial hubs for the eastern part of Indonesia. The overall study involving household solid waste segregation occurs in 14 districts in Makassar, namely: Rappocini, Makassar, Tallo, Tamalanrea, Manggala, Biringkanaya, Tamalate, Mariso, Makassar, Bontoala, Ujung Tanah, Mamajang, Wajo, and Ujung Pandang.

Like any big cities in Indonesia, most waste management authorities only look into the cleanliness of the city just as the final product of SWM, without entirely evaluating the process of SWM itself, whether or not it is the best and correct path towards sustainable solid waste management. One point on solid waste management in Makassar is that, the conventional basic SWM practices are still in place. Although there is a potential point for the city towards the sustainable of solid waste, a concerted effort by multiple stakeholders is necessary (Meidiana and Gamse, 2010).

\section{METHODOLOGY}

This study was undertaken by doing ethnographic observations, structured interview with selected respondents and community leaders as well as distributing questionnaire to randomly selected respondents to understand their perceptions on the cleanliness of the community. By understanding the perceptions of the cleanliness of the surroundings, we then can correlate the perceived cleanliness with the sustainable SWM activities undertaken at the RW level.

Number of respondents (sample size) were calculated according to formula of $\mathrm{n}=\mathrm{N} /\left(1+\mathrm{N}^{*}(\mathrm{e})^{\wedge} 2\right)$, where $\mathrm{N}$ : population size and e: error. In this case, with confidence level of $95 \%$ one-tail, the error is estimated to be $5 \%$, the sample size is then 400 . The response rate was such that there were 412 . The questionnaire was distributed manually and collected within a week or two. Interviews were done with 40 selected respondents, i.e. mostly the champions of the sustainable SWM practices within the community. Key persons within the City Department of Cleanliness were also interviewed to obtain their opinions about solid waste management.

The number of populations in the Districts within Makassar City, number of households, number of households those are presently active practicing sustainable solid waste management activities, and level of sustainable solid waste management practice, as well as sample size is shown in Table 2. The level of sustainable solid waste management practices is measured by the number of households those are currently practicing sustainable solid waste management such as waste reduction, waste separation, waste bank and 3 Rs at household level, per 1,000 population of the district where the households located. By this indicator, the more number of households practicing sustainable SWM the higher the contribution of the district towards sustainable SWM at city level. It is therefore a rational indicator to reflect the level of SWM practices at the household level. 
Sherly Towolioe, Ariva Sugandi Permana, Norsiah A. Aziz, Chin Siong Ho \& Dario G. Pampanga

The Rukun Warga-Based 3Rs and Waste Bank as Sustainable Solid Waste Management Strategy

Table 2: Number of Population and Households those practicing sustainable SWM

\begin{tabular}{|c|c|c|c|c|c|c|c|}
\hline \multirow[b]{2}{*}{ No. } & \multirow{2}{*}{$\begin{array}{l}\text { Districts/ } \\
\text { Townships }\end{array}$} & \multirow{2}{*}{$\begin{array}{l}\text { No of } \\
\text { Population }\end{array}$} & \multirow{2}{*}{$\begin{array}{l}\text { No of } \\
\text { House- } \\
\text { holds }\end{array}$} & \multirow{2}{*}{$\begin{array}{l}\text { Number of } \\
\text { households } \\
\text { actively } \\
\text { practicing } \\
\text { SSWM } \\
\text { (SSWM } \\
\text { Households) }\end{array}$} & \multirow{2}{*}{$\begin{array}{l}\text { Level of } \\
\text { SSWM } \\
\text { Practices* }\end{array}$} & \multicolumn{2}{|c|}{ Respondent } \\
\hline & & & & & & $\begin{array}{l}\text { Min } \\
\dot{\text { Sam }} \\
\text { ple }\end{array}$ & $\begin{array}{l}\text { Acquired } \\
\text { Sample }\end{array}$ \\
\hline 1 & Biringkanaya & 195,906 & 42,458 & 106 & 2.50 & 51 & 54 \\
\hline 2 & Bontoala & 52,631 & 11,405 & 50 & 4.38 & 14 & 17 \\
\hline 3 & Makassar & 81,054 & 17,565 & 108 & 6.17 & 21 & 21 \\
\hline 4 & Mamajang & 58,087 & 13,365 & 90 & 6.77 & 16 & 16 \\
\hline 5 & Manggala & 130,943 & 27,247 & 110 & 4.04 & 33 & 37 \\
\hline 6 & Mariso & 56,578 & 12,457 & 66 & 5.32 & 15 & 18 \\
\hline 7 & Panakukang & 144,997 & 34,791 & 340 & 9.77 & 42 & 42 \\
\hline 8 & Rappocini & 156,665 & 35,449 & 392 & 11.07 & 42 & 45 \\
\hline 9 & Tallo & 138,419 & 28,253 & 516 & 18.30 & 34 & 35 \\
\hline 10 & Tamalanrea & 108,984 & 32,292 & 70 & 2.17 & 39 & 40 \\
\hline 11 & Tamalate & 182,939 & 43,788 & 174 & 3.97 & 52 & 55 \\
\hline 12 & $\begin{array}{l}\text { Ujung } \\
\text { Pandang }\end{array}$ & 26,477 & 5,791 & 20 & 3.44 & 7 & 10 \\
\hline 13 & Ujung Tanah & 46,836 & 9,673 & 40 & 4.12 & 12 & 12 \\
\hline \multirow[t]{2}{*}{14} & Wajo & 27,556 & 6,121 & 23 & 3.76 & 7 & 10 \\
\hline & Total & $1,408,072$ & 320,655 & 2,105 & 6.58 & 384 & 412 \\
\hline
\end{tabular}

Source: Makassar Facts and Figure 2014 (MSO, 2014)

http://makassarkota.bps.go.id/?hal=publikasi detil\&id=37 and Permana et al (2015). Note: *Level of SWM practice was measured as the number of Household $(\mathrm{HH})$, which are actively practiced SSWM, per 1000 of population in the respective districts.

The perceptions on the cleanliness of the surroundings as perceived by the respondents were acquired by employing an easily understood question: How do you feel about the cleanliness of your locality. The responses were given on a 5 point scale as follows: (1) I feel the surrounding are very dirty and messy (2) I feel dirty in the surroundings (3) I feel neither clean nor dirty in the locality (4) It is clean in the surroundings (5) I feel very clean in the surroundings. The level of sustainable solid waste management practices was measured by the proportion of households that actively practiced SSWM (SSWM Households) per 1000 population. The assumption of this measure was that SSWM households where enthusiastically practicing and actively promoting sustainable solid waste management in their locality. Their opinions about solid waste management done by waste management authorities and solid waste management activists were acquired separately.

\section{RESULT AND DISCUSSIONS}

\section{RW as base point of sustainable SWM}

Makassar City consists of 14 sub districts. The 14 sub districts are exhaustively divided into 143 wards, and with similar way, the 143 wards compose of 971 Rukun Warga $(R W)$. In total there are 320,655 households (refer to Table 2). As the base point of sustainable solid waste management, the activities consist of community-based SWM activities. In 
case of Makassar City, the activities are mostly waste separation, 3Rs, composting and waste bank. The small scale solid waste management is commonly found. This is because of minimum supports received from the solid waste management authorities.

The waste separation, waste recyclable selling and waste recyclable banking are three most ubiquitous activities undertaken by the community members, because of several reasons such as (1) strong connections among the three activities (2) creating additional income to all (3) showing the role models that would encourage other community members to actively involved (4) reflecting the commitment of the active community members.

The regular activities of the community members those active in implementing household level sustainable solid waste management and the overall flow of the domestic waste (households as waste generators) in Makassar City can be schematically outlined in Diagram 1.

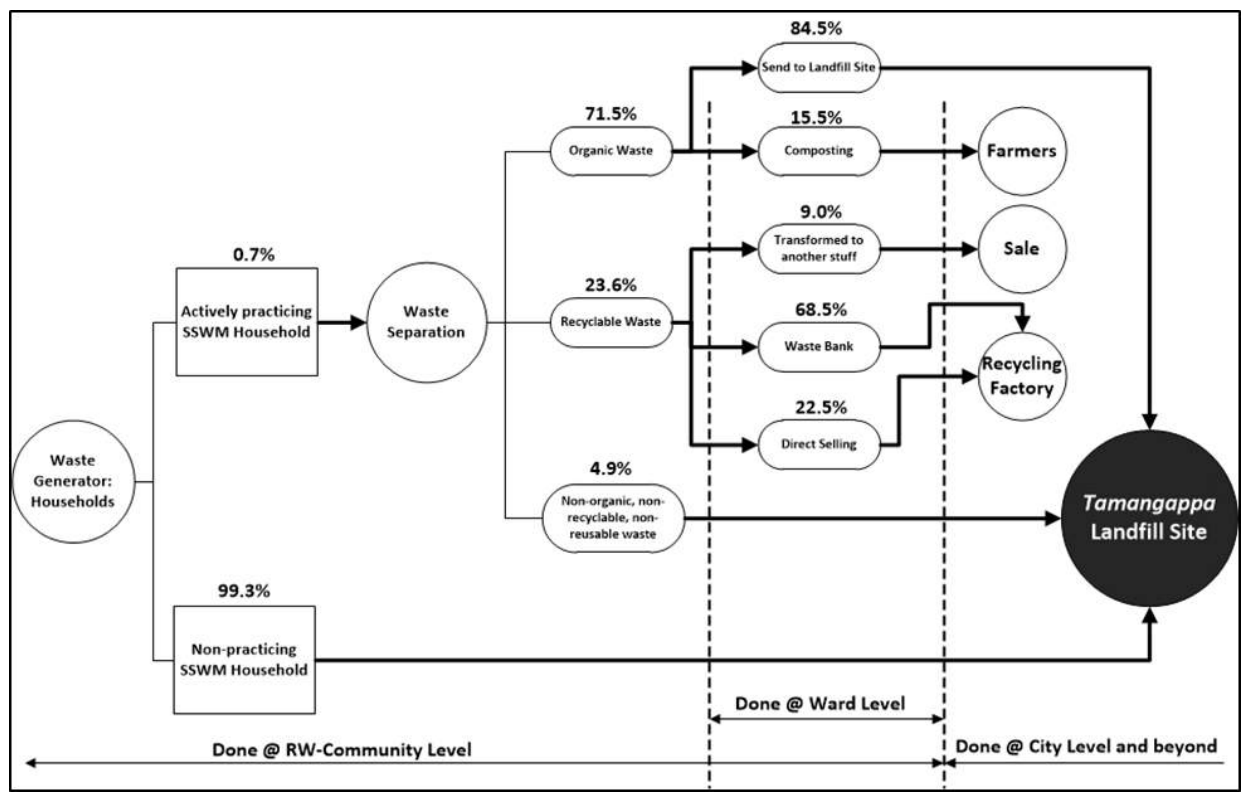

Diagram 1: Domestic Waste Flow in Makassar City

Diagram 1 shows that, in general, the flow of domestic waste is predominantly towards landfill site. The active household in implementing sustainable SWM counts only $0.7 \%$. It is certainly quite insignificant towards overall performance of the City of Makassar in sustainable SWM. As a result, the Tamangappa Landfill site, the only disposal site is presently in operation in Makassar City, will soon be needed to replace. The NIMBY, on the other hand, is also strong within the urban citizens, and also in Makassar. Thus, the waste authority will seemingly face the social problems soon when the only landfill site available needs replacement.

The sustainable SWM activities at RW level consists of waste separation and first stage of 3Rs activities. Beyond that level, the active household must undertake their activities at wards or city level. Recycling factories are commonly operated beyond city 
Sherly Towolioe, Ariva Sugandi Permana, Norsiah A. Aziz, Chin Siong Ho \& Dario G. Pampanga

The Rukun Warga-Based 3Rs and Waste Bank as Sustainable Solid Waste Management Strategy

level, or even exporting the recycled materials to other countries. However, the RW-based sustainable SWM is the basis of overall SWM in Makassar City. The failure and success of the sustainable solid waste management would depend on the performance of them. It is therefore need very strong supports from solid waste stakeholders in order to be able to perform well.

\section{Community Waste Banks}

Figure 1 reflects that the predominant waste in Makassar is organic waste, which is accounted for $71.5 \%$, while the other $23.6 \%$ is recyclable waste. The active households are thus depending on this amount of waste. While only about fifteen percent of the organic waste is composted domestically through household-based Takakura composting basket, the most of waste is disposed to landfill site.

From $23.6 \%$ recyclable waste, about $9 \%$ is transformed into another usable stuff such as handy-craft, the remaining $91 \%$ is for direct sale to the recycling factory or deposited to Waste Bank, and then waste bank sells it to recycling factory. There are presently 105 waste bank who have registered in $105 \mathrm{RW}$. Among these 105 waste banks, the largest and very active waste bank is Waste Bank Pelita Harapan in Rappocini sub district at RM IV Ballaparang Ward (Figure 2). This Waste Bank has presently 202 active household customers that do waste separation at household and sell the recyclables to this Bank.

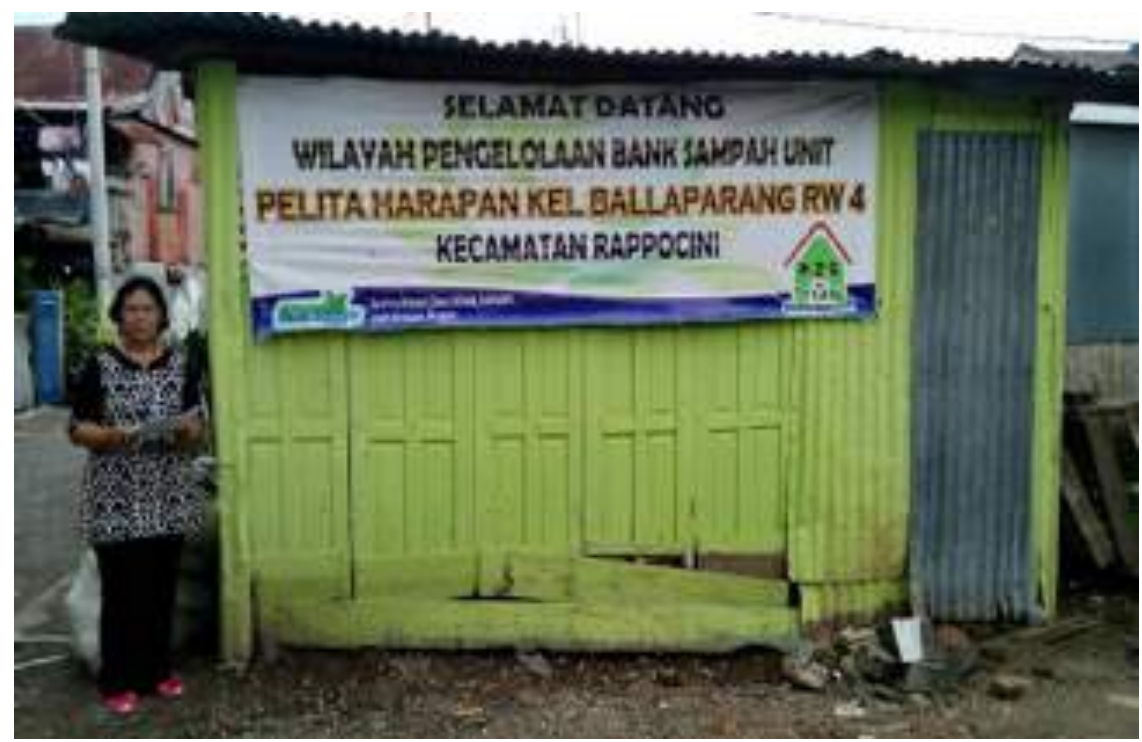

Figure 2: Pelita Harapan Waste Bank

The first author of this paper has become registered members \#201 since 27 April 2015. The majority of Bank's members of this waste bank live within RW IV Ballaparang Ward. Some other members are from other Wards. The Chairman of the Waste Bank is the Leader of RW IV. About $90 \%$ of the Waste Bank Officers are housewives who work voluntarily; they are unpaid workers (Figure 3). Bookkeeping management recorded 
neatly by an Administrative Officer. Receiving and weighing the waste ends up at $5 \mathrm{pm}$ every Sunday. Bank operating costs derived from the sale of wastes.

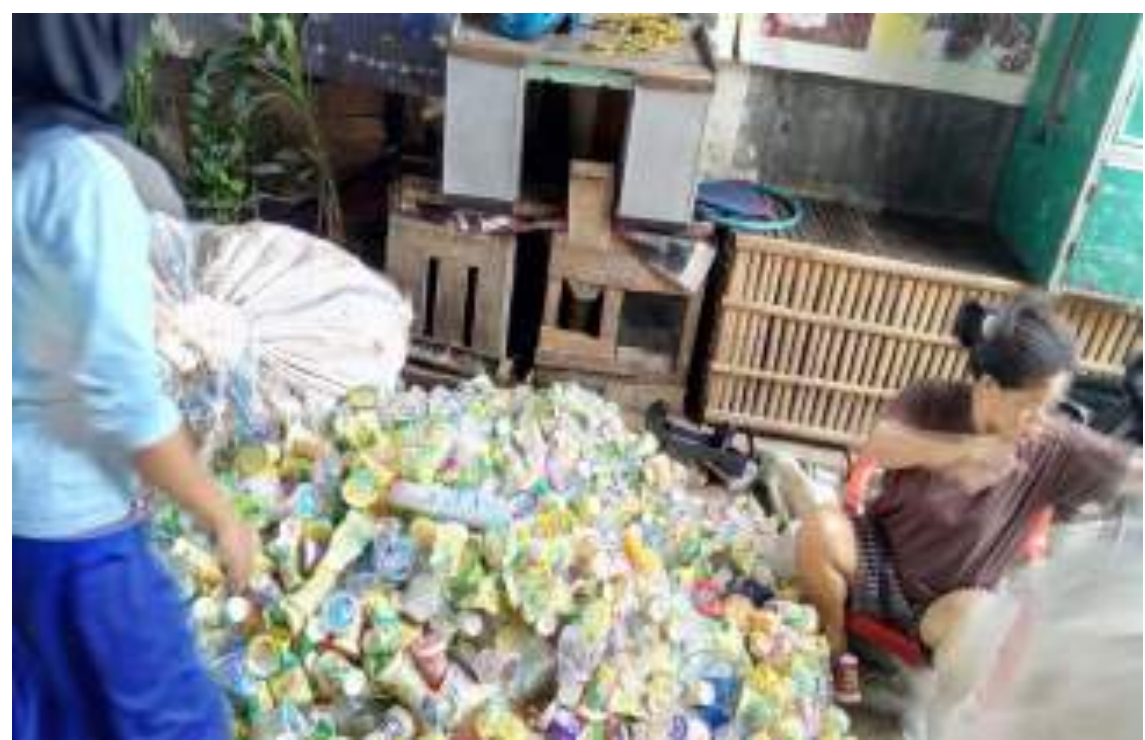

Figure 3: Waste Bank Businesses

All the 105 waste banks are presently active (Table 3 ), although their activities and performances are at different level. All the banks serve for the community and by the community with RW organization as the basis of their operation. All the officers work voluntarily without payment. The officers are usually people with high commitment on their community and or people with somewhat higher-than-average income. These waste banks are headed by RW Community Leader. The municipal waste authorities do not provide any financial support rather some technical supports such as training on solid waste management for the waste bank officers and champions within the communities.

Table 3: RW-based Waste Bank Organizations in Makassar city

\begin{tabular}{cclll} 
NO & & & Waste Bank & Reg. \\
& & & \multicolumn{1}{c}{ Name of Waste Bank } & Number \\
\cline { 2 - 5 } & RW & Wards & Pelita Harapan & MKS-01 \\
\hline 1 & 4 & Ballaparang & Restu Bumi & MKS-02 \\
\hline 2 & 2 & Kalukuang & Mandiri & MKS-03 \\
\hline 3 & 2 & Tamamaung & Sehati & MKS-04 \\
\hline 4 & 1 & Ujung Pandang Baru & Pabaeng-Baeng 5 & MKS-05 \\
\hline 5 & 5 & Pabaengbaeng & Mekar Swadaya & MKS-06 \\
\hline 6 & 8 & Bangkala & Pasang Surut & MKS-07 \\
\hline 7 & 4 & Cambaya & Sipakatau & MKS-08 \\
\hline 8 & 3 & Karanganyar & Lalatang & MKS-09 \\
\hline 9 & 2 & Lalatang & Asoka 6 & MKS-10 \\
\hline 10 & 6 & Bongaya & Panaikang & MKS-11 \\
\hline 11 & 5 & Panaikang & &
\end{tabular}


Sherly Towolioe, Ariva Sugandi Permana, Norsiah A. Aziz, Chin Siong Ho \& Dario G. Pampanga

The Rukun Warga-Based 3Rs and Waste Bank as Sustainable Solid Waste Management Strategy

\begin{tabular}{|c|c|c|c|c|}
\hline 12 & 4 & Bongaya & Asoka 4 & MKS-12 \\
\hline 13 & 4 & Pannampu & Tunas Harapan & MKS-13 \\
\hline 14 & 5 & Kassi-Kassi & Durian & MKS-14 \\
\hline 15 & 1 & Tamalanrea Jaya & Bung & MKS-15 \\
\hline 16 & 1 & Suwangga & Cahaya Suangga & MKS-16 \\
\hline 17 & 5 & Layang & Layang Sehati & MKS-17 \\
\hline 18 & 5 & Kunjung Mae & Keraku Marga 04 & MKS-18 \\
\hline 19 & 5 & Rappokalling & Mutiara & MKS-19 \\
\hline 20 & 5 & Jongaya & Kumala & MKS-20 \\
\hline 21 & 3 & Karuwisi Utara & Adipura & MKS-21 \\
\hline 22 & 1 & Ballaparang & Pelita Bangsa & MKS-22 \\
\hline 23 & 5 & Sudiang & Cumullus & MKS-23 \\
\hline 24 & 1 & Lalatang & Star & MKS-24 \\
\hline 25 & 4 & Bara-Baraya Selatan & Sukses Mulia & MKS-25 \\
\hline 26 & 10 & Mappala & Bersatu & MKS-26 \\
\hline 27 & 11 & Tello Baru & Tello Ceria & MKS-27 \\
\hline 28 & 5 & Tanjung Mardeka & Tanjung Bayang & MKS-28 \\
\hline 29 & 2 & Maradekaya & Maradekaya & MKS-29 \\
\hline 30 & 3 & Maricaya Baru & Maribar 03 & MKS-30 \\
\hline 31 & 5 & Bara-Baraya & Asbar Ceria & MKS-31 \\
\hline 32 & 9 & Bongaya & Titian Sejahtera & MKS-32 \\
\hline 33 & 8 & Pabaengbaeng & Bersatu & MKS-33 \\
\hline 34 & 11 & Barombong & Berdikari & MKS-34 \\
\hline 35 & 11 & Sudiang Raya & Sudira & MKS-35 \\
\hline 36 & 2 & Bira & Bira 2 & MKS-36 \\
\hline 37 & 3 & Tamalanrea Jaya & Tunas Mekar & MKS-37 \\
\hline 38 & 2 & Ballaparang & Dahlia 2 & MKS-38 \\
\hline 39 & 5 & Bontomakkio & Bersatu & MKS-39 \\
\hline 40 & 3 & Gaddong & Mandiri & MKS-40 \\
\hline 41 & 3 & Bara-Baraya Timur & Bartim & MKS-41 \\
\hline 42 & 4 & Suwangga & Suwangga 4 & MKS-42 \\
\hline 43 & 3 & Camba Berua & Tawakkal & MKS-43 \\
\hline 44 & 4 & Pattingalloang & Pattingalloang 4 & MKS-44 \\
\hline 45 & 1 & Mappala & Mappala 1 & MKS-45 \\
\hline 46 & 13 & Gunung Sari & Minasa Upa & MKS-46 \\
\hline 47 & 4 & Karungrung & Jipang 04 & MKS-47 \\
\hline 48 & 1 & Maradekaya & Maradekaya 1 & MKS-48 \\
\hline 49 & 2 & Tamalabba & Bersinar & MKS-49 \\
\hline 50 & 5 & Untia & Cahaya Bahari & MKS-50 \\
\hline 51 & 1 & Mampu & Mampu 1 & MKS-51 \\
\hline 52 & 2 & Bonto Lebang & Bonto Lebang & MKS-52 \\
\hline 53 & 1 & Barrang Lompo & Samaturu & MKS-53 \\
\hline 54 & 1 & Rappokalling & Sipakainga & MKS-54 \\
\hline 55 & 1 & Karuwisi & Citra Abadi & MKS-55 \\
\hline 56 & 7 & Ballaparang & Glatik & MKS-56 \\
\hline 57 & 1 & Tallo & Rakyat Tallo & MKS-57 \\
\hline 58 & 9 & Ballaparang & Gotong Royong & MKS-58 \\
\hline 59 & 8 & Batua & Bampasker & MKS-59 \\
\hline 60 & 1 & Tamalabba & Hoki 1 & MKS-60 \\
\hline 61 & 2 & Rappokalling & Berlian & MKS-61 \\
\hline 62 & 3 & Rappokalling & Permata Bunda & MKS-62 \\
\hline 63 & 5 & Kaluku Bodoa & Permata & MKS-63 \\
\hline 64 & 5 & Rappocini & Monginsidi & MKS-64 \\
\hline 65 & 5 & Buakana & Harapan & MKS-65 \\
\hline 66 & 10 & Barombong & Danau Biru & MKS-66 \\
\hline
\end{tabular}




\begin{tabular}{|c|c|c|c|c|}
\hline 67 & 3 & Maccini S0mbala & Je'neberang & MKS-67 \\
\hline 68 & 9 & Mappala & Bunga Tonjong & MKS-68 \\
\hline 69 & 4 & Tallo & Marbo Bahari & MKS-69 \\
\hline 70 & 2 & Lae-Lae & Intang & MKS-70 \\
\hline 71 & 2 & Tallo & Lestari & MKS-71 \\
\hline 72 & 3 & Barana & Melati & MKS-72 \\
\hline 73 & 4 & Tamalanrea & Cokro Indah & MKS-73 \\
\hline 74 & 13 & Tamalanrea & Berlian & MKS-74 \\
\hline 75 & 9 & Bulurokeng & Mutiara Asri & MKS-75 \\
\hline 76 & 9 & Sudiang Raya & Rahmat & MKS-76 \\
\hline 77 & 14 & Bulurokeng & Indah Berseri & MKS-77 \\
\hline 78 & 12 & Bulurokeng & Mutiara Jelita & MKS-78 \\
\hline 79 & 4 & Camba Berua & Camber 4 & MKS-79 \\
\hline 80 & 1 & Sudiang Raya & Gelora & MKS-80 \\
\hline 81 & 2 & Ende & Rezki & MKS-81 \\
\hline 82 & 1 & Lembo & Sipurennu & MKS-82 \\
\hline 83 & 21 & Sudiang Raya & Citra Daya & MKS-83 \\
\hline 84 & 10 & Parang Tambung & Peduli Lingkungan & MKS-84 \\
\hline 85 & 4 & Rappokalling & Bersinar & MKS-85 \\
\hline 86 & 5 & Bongaya & Surya Abadi & MKS-86 \\
\hline 87 & 18 & Sudiang Raya & Berkah & MKS-87 \\
\hline 88 & 5 & Tallo & Rajata & MKS-88 \\
\hline 89 & 5 & Tamamaung & Matahari & MKS-89 \\
\hline 90 & 7 & Batua & Batua & MKS-90 \\
\hline 91 & 3 & Maradekaya & Maradekaya & MKS-91 \\
\hline 92 & 3 & Tallo & Rempong & MKS-92 \\
\hline 93 & 5 & Lette & Peduli & MKS-93 \\
\hline 94 & 1 & Mariso & Nuri Indah & MKS-94 \\
\hline 95 & 1 & Tamalanrea Indah & Tamalanrea Indah & MKS-95 \\
\hline 96 & 6 & Paccerakkang & Indah & MKS-96 \\
\hline 97 & 3 & Paccerakkang & Sakinah & MKS-97 \\
\hline 98 & 5 & Lembo & Sikatutui & MKS-98 \\
\hline 99 & 2 & Lembo & Sipakalebbiri & MKS-99 \\
\hline 100 & 1 & Maricaya Selatan & Kenanga & MKS-100 \\
\hline 101 & 5 & Tamamaung & Matahari & MKS-101 \\
\hline 102 & 1 & Rappocini & Agang Ta' & MKS-102 \\
\hline 103 & 3 & Pisang Selatan & Pissel & MKS-103 \\
\hline 104 & 1 & Bontoala & Cempaka & MKS-104 \\
\hline 105 & 1 & Karunrung & Karya 2 & MKS-105 \\
\hline
\end{tabular}

The financial income received by the members of Waste Banks has helped increasing their household disposable income. This can be seen on the total amount disbursed of about USD 36,000 to the members of garbage bank (Yayasan Peduli Negeri -YPN, 2013). The benefits for public waste bank were able to increase the income of the people because when they exchange their garbage will receive remuneration in the form of money collected in the accounts they have. Society may, at any time, take the money at the time savings already collected a lot of savings. Rewards given to depositors not only in the form of money, but some are in the form of basic foodstuffs such as sugar, soap, oil and rice. Bank of garbage is also beneficial for students who are disadvantaged in terms of financial; some schools have implemented tuition payments using the garbage.

Until now, the average monthly waste collection is 30 kilograms up to two tons of recyclable waste per month per unit of waste banks, with a turnover of hundreds of 
Sherly Towolioe, Ariva Sugandi Permana, Norsiah A. Aziz, Chin Siong Ho \& Dario G. Pampanga

The Rukun Warga-Based 3Rs and Waste Bank as Sustainable Solid Waste Management Strategy

thousands dollars per month This proves that the bank system does not only reduce the amount of garbage bins, but also be a solution for the welfare of society as well as it can increase revenue and improve the local economy. Makassar city itself has been able to reduce waste as much as 281 tons of organic waste in 2000. The existence of Garbage Bank has a positive impact in the community, only the pilot project has not been widely followed by other RW. While the relevant agencies and industry, yet in synergy with the Waste Bank practice in the field, giving the impression of each walk alone whereas the issue of waste must be ganged together with synergy with one another.

By the activities of waste bank, the local government of Makassar City has included the waste bank program in Makassar Clean and Green City. The Makassar Clean and Green City has also involved the private sector, particularly industries those generate waste through their own Corporate Social Responsibility (CSR) Program. Makassar efforts in making Waste Bank Program as one of the priority program of Makassar Green and Clean has received positive feedback from various parties. One of them is Unilever Company as a partner Makassar Clean and Green since 2008. Unilever Indonesia Foundation (YUI) as its corporate social responsibility activity participates in tackling social and environmental issues in the Makassar Clean and Green Program.

Some companies whose activities have an impact on the environment have started establishing CSR activities that care for the environment and voluntarily disclose their CSR performance in a variety of ways, either through a special and separate program, as well as being part of the annual program. Another important thing, so that people can feel the most out of CSR activities of the company is maintained environmental sustainability of the CSR activities. Four alternative areas of environmental CSR activities include: (1) Waste Management through the process of Reduce, Reuse and Recycle (3R); (2) Some existing CSR activities carried out only for a moment and unsustainable so that targets are not met; (3) Tree planting activities (4) Funding schemes. The Rukun Warga approach in waste reduction especially in the urban center has been able to contribute to the reduction of waste disposal to landfill site in Makassar. Its significance can be seen in the reduction of total volume of solid waste by $12 \%$ (dry waste) and $17 \%$ of organic waste (wet waste) in 2013 disposed to landfill site.

\section{Community Waste Composting}

Nowadays, city government attempts to help citizens in doing composting at household level by providing Takakura's magic basket to selected households. Takakura's magic basket is a basket that 'magically' transfers waste into compost. This is also called Takakura Home Method, named after Mr. Koji Takakura, a researcher of Wakamatsu Environmental Research Institute, Japan (ECO-CSR, 2015). Households who practice waste composting usually put their organic wastes into a basket called Takakura's magic basket to turn into compost in a natural process. If this movement can be done at city level, a significant quantity of organic waste can be diverted from the disposal site to more useful waste.

Realizing the large quantity of organic waste, some large cities in Indonesia have already been making efforts to reduce waste by trying to adopt feasible composting technology as part of waste reduction. However, some composting ventures have collapsed due to the absence of market for its finished products and not meeting the requirement of the market aside from its high price (Damanhuri and Padmi, 2000). Market 
is the most problem in composting in almost all developing countries. The final product of composting is agricultural fertilizer, while there are presently chemical fertilizers in the market which the price is probably lower than composting product fertilizer. In addition, the farmers have been customary to use chemical fertilizer products and some reports show that the productivity of plants that use chemical fertilizer is higher than that of use composting fertilizer. By this condition, the composting fertilizer is difficult to compete with chemical fertilizer amid biodegradability and contribution to waste reduction of composting fertilizer. This is why the progress of waste composting is almost standing still.

We can see themselves in the environment around the city, the unavailability of landfills. In this case the government should provide adequate landfills for each region in order to avoid the name of littering that can cause environmental pollution. It is known that in urban areas the buildings so close together to landfills is very limited which makes people throw garbage city is not in place although it contains the warning signs prohibiting to dispose of waste on the site. Constitution no. 23, 1997 Article 6, paragraph 1, which reads: "Every person is obliged to preserve the function of the environment as well as prevent and control pollution and environmental destruction". To achieve the condition of the people who live healthy and prosperous in the future, it will be necessary for a healthy living environment. From the aspect of waste, then the word will mean healthy as conditions that would be achieved if the waste can be managed well so clean from neighborhoods where human activity in it (Minister of Public Works Regulation 21/PRT/M/2006)

\section{Perceived Cleanliness in the Locality}

Cleanliness is a state free of impurities, including, dust, garbage and odors. (www.wikipedia.com). Cleanliness can also be regarded as a sterile state, free from dirt and reflect the holiness and purity. According to Mustafa, a community leader, and the environment are all external factors, physical, and biological directly adhered to the survival, growth, and reproductive development of organisms. Furthermore, the environment is a natural state of human society interacts.

We acquired the perception on cleanliness of the surroundings from the selected residents in the wards, in connection with the solid waste management activities in the community. The cleanliness as perceived by the residents was acquired by asking them a plain and easily understood question: How do you feel about the cleanliness of your locality. The responses were given on a 5 point scale as follows: (1) I feel the surrounding are very dirty and messy (2) I feel dirty in the surroundings (3) I feel neither clean nor dirty in the locality (4) It is clean in the surroundings (5) I feel very clean in the surroundings. 
Sherly Towolioe, Ariva Sugandi Permana, Norsiah A. Aziz, Chin Siong Ho \& Dario G. Pampanga

The Rukun Warga-Based 3Rs and Waste Bank as Sustainable Solid Waste Management Strategy

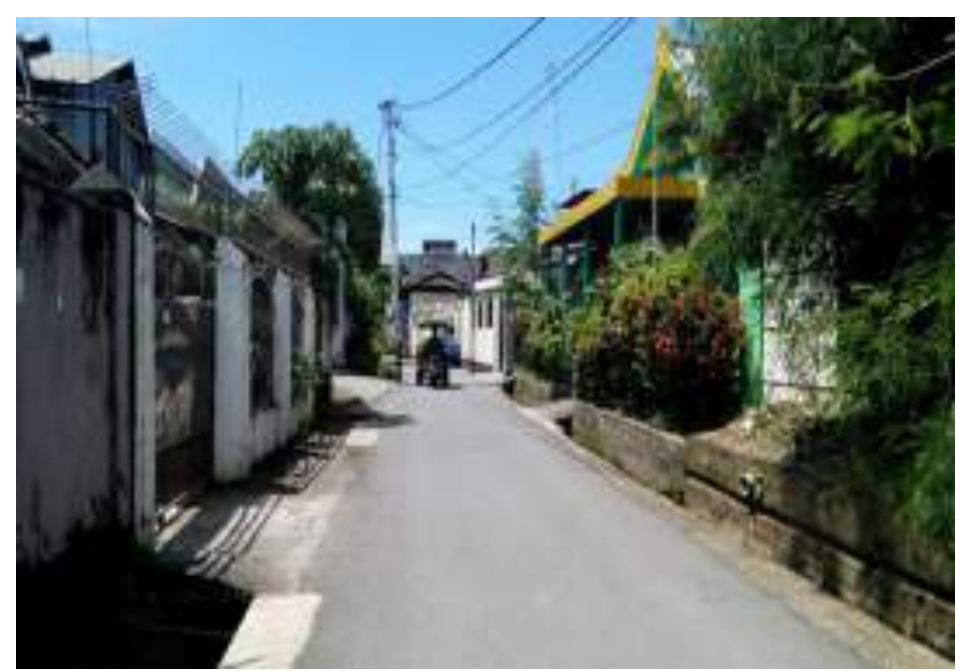

Figure 4: A Sample of Clean Environment as perceived by Respondents

By this question, the responses are summarized in Table 4. It is can easily be seen that when the level of sustainable SWM activities in the community is high, the surrounding is perceived clean by the community.

Table 4: Perceived Cleanliness and Level of Sustainable SWM

\begin{tabular}{|c|c|c|c|c|c|c|c|}
\hline \multirow{2}{*}{ Township } & \multirow{2}{*}{ Item } & \multicolumn{5}{|c|}{ Perceived Cleanliness (1=Dirties, 5=Cleanest) } & \multirow{2}{*}{$\begin{array}{l}\text { Level of } \\
\text { SSWM* }\end{array}$} \\
\hline & & 1 & 2 & 3 & 4 & 5 & \\
\hline \multirow[b]{2}{*}{ Biringkanaya } & Count & 9 & 34 & 11 & 0 & 0 & \multirow[b]{2}{*}{2.50} \\
\hline & $\%$ & $\begin{array}{r}16.7 \\
\%\end{array}$ & $63.0 \%$ & $20.4 \%$ & $0.0 \%$ & $0.0 \%$ & \\
\hline \multirow[b]{2}{*}{ Bontoala } & Count & 3 & 6 & 8 & 0 & 0 & \multirow[b]{2}{*}{4.38} \\
\hline & $\%$ & $\begin{array}{r}17.6 \\
\%\end{array}$ & $35.3 \%$ & $47.1 \%$ & $0.0 \%$ & $0.0 \%$ & \\
\hline \multirow{2}{*}{ Makassar } & Count & 2 & 3 & 14 & 2 & 0 & \multirow{2}{*}{6.15} \\
\hline & $\%$ & $9.5 \%$ & $14.3 \%$ & $66.7 \%$ & $9.5 \%$ & $0.0 \%$ & \\
\hline \multirow[b]{2}{*}{ Mamajang } & Count & 2 & 3 & 7 & 4 & 0 & \multirow[b]{2}{*}{6.73} \\
\hline & $\%$ & $\begin{array}{r}12.5 \\
\%\end{array}$ & $18.8 \%$ & $43.8 \%$ & $25.0 \%$ & $0.0 \%$ & \\
\hline \multirow{2}{*}{ Manggala } & Count & 2 & 4 & 20 & 11 & 0 & \multirow{2}{*}{4.04} \\
\hline & $\%$ & $5.4 \%$ & $10.8 \%$ & $54.1 \%$ & $29.7 \%$ & $0.0 \%$ & \\
\hline \multirow{2}{*}{ Mariso } & Count & 1 & 4 & 8 & 5 & 0 & \multirow{2}{*}{5.30} \\
\hline & $\%$ & $5.6 \%$ & $22.2 \%$ & $44.4 \%$ & $27.8 \%$ & $0.0 \%$ & \\
\hline \multirow{2}{*}{ Panakukang } & Count & 1 & 2 & 9 & 28 & 2 & \multirow{2}{*}{9.77} \\
\hline & $\%$ & $2.4 \%$ & $4.8 \%$ & $21.4 \%$ & $66.7 \%$ & $4.8 \%$ & \\
\hline \multirow{2}{*}{ Rappocini } & Count & 0 & 0 & 8 & 26 & 11 & \multirow{2}{*}{11.06} \\
\hline & $\%$ & $0.0 \%$ & $0.0 \%$ & $17.8 \%$ & $57.8 \%$ & $24.4 \%$ & \\
\hline \multirow{2}{*}{ Tallo } & Count & 0 & 0 & 13 & 14 & 8 & \multirow{2}{*}{18.26} \\
\hline & $\%$ & $0.0 \%$ & $0.0 \%$ & $37.1 \%$ & $40.0 \%$ & $22.9 \%$ & \\
\hline \multirow[b]{2}{*}{ Tamalanrea } & Count & 8 & 17 & 13 & 2 & 0 & \multirow[b]{2}{*}{2.17} \\
\hline & $\%$ & $\begin{array}{r}20.0 \\
\%\end{array}$ & $42.5 \%$ & $32.5 \%$ & $5.0 \%$ & $0.0 \%$ & \\
\hline \multirow{2}{*}{ Tamalate } & Count & 0 & 12 & 32 & 11 & 0 & \multirow{2}{*}{3.97} \\
\hline & $\%$ & $0.0 \%$ & $21.8 \%$ & $58.2 \%$ & $20.0 \%$ & $0.0 \%$ & \\
\hline
\end{tabular}




\begin{tabular}{|c|c|c|c|c|c|c|c|}
\hline \multirow{2}{*}{ Ujungpandang } & Count & 0 & 5 & 5 & 0 & 0 & \multirow{2}{*}{3.45} \\
\hline & $\%$ & $0.0 \%$ & $50.0 \%$ & $50.0 \%$ & $0.0 \%$ & $0.0 \%$ & \\
\hline \multirow{2}{*}{ Ujungtanah } & Count & 0 & 5 & 6 & 1 & 0 & \multirow{2}{*}{4.14} \\
\hline & $\%$ & $0.0 \%$ & $41.7 \%$ & $50.0 \%$ & $8.3 \%$ & $0.0 \%$ & \\
\hline \multirow{2}{*}{ Wajo } & Count & 0 & 3 & 7 & 0 & 0 & \multirow{2}{*}{3.76} \\
\hline & $\%$ & $0.0 \%$ & $30.0 \%$ & $70.0 \%$ & $0.0 \%$ & $0.0 \%$ & \\
\hline \multirow{2}{*}{ TOTAL } & Count & 28 & 98 & 161 & 104 & 21 & \\
\hline & $\%$ & $6.8 \%$ & $23.8 \%$ & $39.1 \%$ & $25.2 \%$ & $5.1 \%$ & \\
\hline
\end{tabular}

Table 4 shows that Panakukang, Rappocini and Tallo are three sub-districts that are perceived the cleanest by the local respondents, as majority of the respondents perceived clean and very clean (Scale 4 to 5). The Table also shows that higher percentage of the citizens in these three sub-districts who are engaging in the sustainable SWM activities. On the other hand, Tamalanrea, Biringkanaya, Bontoala, Mamajang and Makassar are the dirtiest sub-districts in Makassar City. In these districts, the level of engagement of the residents in the sustainable SWM activities is lower than the top-three sub-districts. By this finding, it is confirmed that the level of sustainable SWM activities is strongly associated with the perceived cleanliness. This finding also tells us that there should be more citizens engaging in sustainable solid waste management activities to accomplish the highly perceived environmental cleanliness. This is depending on the existing and future policies of the central and local government and willingness of these two level of government, and most importantly is the awareness of citizens.

\section{CONCLUSIONS AND THE WAY FORWARD}

There are actually sufficient set of Acts and Government Regulations associated with solid waste management in place at the national level. For example, Act 18/2008 regarding Solid Waste Management (UURI: 18/2008), Government Regulation 81/2012 on Municipal Solid Waste (PP: 81/2012), Minister of Environment's Regulation 13/2012 on 3Rs and Makassar City Regulation 4/2011 on Waste Separation at Household Level have been enacted. The weakness point lies on the implementation side, particularly on the capacity of the authority.

The institutional setting at community level for the up-scaling sustainable SWM in the whole city is in place. $R W$ can be used as the basic point of the institutional setting at community level. The embryos are existing, the remaining work is to strengthen these embryos towards certain level of strength to sustain.

What the local government need to do are (1) strengthening the community-based institutional setting by reinforcing RW organization in handling sustainable solid waste management at community level (2) upscaling the present RW-based sustainable SWM to city level by duplicating the existing RW-based activities to other RWs, (3) allocating and providing an financial incentives and supports for the SSWM households.

\section{ACKNOWLEDGMENT}

We would like to thank the Ministry of Higher Education (MOHE) and Research Management Centre (RMC) at the Universiti Teknologi Malaysia (UTM) under Research University Grant Category (VOT234678) for supporting this work. 
Sherly Towolioe, Ariva Sugandi Permana, Norsiah A. Aziz, Chin Siong Ho \& Dario G. Pampanga

The Rukun Warga-Based 3Rs and Waste Bank as Sustainable Solid Waste Management Strategy

\section{REFERENCES}

Bai, R., \& Sutanto, M. (2002). The practice and challenges of solid waste management in Singapore. Waste Management, 22, 557-567. Retrieved from www.elsevier.com/locate/wasman

Central Bureau of Statistics, Makassar (2013). Makassar: Facts and Figures - Makassar dalam Angka 2010-2012.

Central Bureau of Statistics, Makassar (2014). Makassar: Facts and Figures - Makassar dalam Angka 2013

Damanhuri, E., \& Padmi, T. (2011). Pengelolaan sampah. INSTITUT TEKNOLOGI BANDUNG

Dilla, M., \& Natsir, M. T. (2007). Basline Services of Community and Cleaning Agency for Municipal Solid Waste Management In Makassar of South Sulawesi. Environmental Engineering, 2(2), 63-66. Retrieved from http://trisanita.org/jases/asespaper2007/ases08v2n2y2007.pdf

Eco-CSR (2015). Japan International Cooperation in CSR. Available online at http://www.env.go.jp/earth/coop/eco-csrjapan/en/case_2.html (retrieved 20 May 2015).

Matter, A., Dietschi, M., \& Zurbrügg, C. (2013). Improving the informal recycling sector through segregation of waste in the household - The case of Dhaka Bangladesh. Habitat International, 38, 150-156. doi:10.1016/j.habitatint.2012.06.001

McBean, E.A., Rosso, E., Rovers, F.A. (2005). Improvement in financing for sustainability in solid waste management. Journal of Resources, Conservation and Recycling 43, 391401.

Meidiana, C., \& Gamse, T. (2010). Development of Waste Management Practices in Indonesia. European Journal of Scientific Research, 40(2), 199-210.

Parizeau, K., Virginia, M., Chanthy, L. (2006). Waste characterization as an element of waste management planning: lessons learned from a study in Siem Reap, Cambodia. Resources, Conservation and Recycling 49 (2), 110-128

Pasang, H., Moore, G. \& Sitorus, G. (2007). Neighbourhood-based waste management: a solution for solid waste problems in Jakarta, Indonesia. Waste Management (New York, N.Y.), 27(12), 1924-38. doi:10.1016/j.wasman.2006.09.010

Permana AS, S. Towolioe, NA Aziz, CS Ho (2015). Sustainable solid waste management practices and perceived cleanliness in low income city. Habitat International, 49:197205. DOI: http://dx.doi.org/10.1016/j.habitatint.2015.05.028

Public Cleansing Department, Makassar (2013). Waste Generation and Composition of Makassar City Year 2009 - Year 2013.

Ryu, C. (2010). Potential of Municipal Solid Waste for Renewable Energy Production and Reduction of Greenhouse Gas Emissions in South Korea. Journal of the Air \& Waste Management Association, 60(2), 176-183. doi:10.3155/1047-3289.60.2.176

Visvanathan, C., Adhikari, R., \& Ananth, A. P. (2007). 3R Practices for Municipal Solid Waste Management In Asia. Retrieved from http://www.faculty.ait.ac.th/visu/Prof Visu\%27s CV/Conferance/3/Visvanathan_Kalmar07.checked. Latested submitted.pdf

World Bank. (2007). Addendum to Makassar Landfill Gas Project - Environmental Due Diligence.

Yayasan Peduli Negeri, YPN (2013). Waste Bank Motivator: Summary Data of Waste Type in Makassar City - Data Rekapitulasi Produk Sampah Per Kelompok Jenis Sampah Kota Makassar. Makassar. 